\title{
Critical Review Of Darwin Evolution Theory And Debilitating Facts
}

\author{
Susanto \\ \{susanto280266@gmail.com\} \\ Department of Biology Education, Faculty of Teacher Training and Education, Universitas \\ Muhammadiyah Purwokerto
}

\begin{abstract}
Science is not an eternal building, because science is actually something that is never finished. Although science is based on an objective, rational, systematic, logical and empirical framework, in its development, science cannot be separated from the mechanism of openness to correction. In other words, the truth of science is not absolute truth. The truth of science is a relative truth. That is why, humans are required to always look for development alternatives, both those concerning the methodological, ontological, axiological, and epistemological aspects. Therefore, every scientific development that is born, at least its validity and truth can be accounted for both based on the context of justification and context of discover. Although the theory of evolution is considered by many scientists as a challenge to the beliefs of some religious, ethical, and even scientific beliefs of its time, referring to all the verses of the Qur'an regarding the creation of man, we find that the Qur'an will not face these challenges. at all. This is because the verses in it correspond to the direct creation of man, rather than the gradual and gradual creation, or can be taken as an implied meaning. Humans from Adam's generation can be considered the exception to this theory. However, if there are Muslim scholars who accept the theory of evolution, they believe that the structural uniformity of living things is the result of divine thought rather than mere random coincidences in nature.
\end{abstract}

Keywords: Critical Review, Darwin Evolution Theory, Debilitating Facts

\section{Introduction}

A scientist must be capable of figuring out facts from observation and use other scientist thoughts that not limited to his/her field of science, to became integrated scientifical thought. This is what Charles Darwin did when he developed his natural selection theory. In advancing his thoughts about the origins of species, Darwin show his brilliance about it. He also show his greatness on respect to another finding from people before him. Beside he shows courage to not defending common known and rooted opinion, if as a scientist he founds facts that not in accordance with common opinions and means he could face the risk of blasphemy (Nasoetion, $1988: 159-160)$. 
Science is not an eternal building, because science is actually something that is never finished. Although science is based on an objective, rational, systematic, logical and empirical framework, in its development, science cannot be separated from the mechanism of openness to correction. In other words, the truth of science is not absolute truth. The truth of science is a relative truth. That is why, humans are required to always look for development alternatives, both those concerning the methodological, ontological, axiological, and epistemological aspects. Therefore, every scientific development that is born, at least its validity and truth can be accounted for both based on the context of justification and context of discover (Fannie, 1994: v - vi).

History has shown that at first the branch of science was rooted in philosophy. With the release of this bond from philosophy, specialism becomes increasingly intensive on the one hand, but on the other hand makes us no longer recognize the source of philosophical thought, so that emerge scientists who lose their vision and philosophical orientation (Siswomihardjo, 1994: 17-18). Furthermore, it is explained that philosophy that will encourage us to expand our knowledge horizons, the sharpness of our reflection, the depth of our imagination, the sensitivity of our intuition in such a way as to avoid us from the sickening simplistic thinking, from intellectual hazziness, drifting in the currents of the scientific tradition. It is very dangerous if we think that science is a finished product, stagnant-finished, closed from any possible change and renewal.

Higgins (2004: 42) explains the thought of Philo of Alexandria ( $\pm 20 \mathrm{BC}-50 \mathrm{BC}$ ) that God constantly regulates all things through His mind. His thinking did not precede His creation, and never once did He not create. The forms themselves have been with Him from the beginning. So by constantly thinking He creates and completes all visible things with their principle of existence so that they coexist: the Divine Mind which is always creating and everything sensuous and visible to which it was given a beginning could be exists. From preelemental matter God created all things, without holding them, for it is not justified for Him who is happy and blessed to touch chaotic and limited matter. Instead, He uses immaterial powers, to create forms that have been completely designed, so that each genus acquires its corresponding form. God, as God, has foreordained that a beautiful imitation cannot be produced except from a beautiful pattern and that no sensuous object will be perfect if it is not shaped according to an ancient and understandable idea.

One new force involved in this war is Intelligent Design, which we will hereinafter call ID. Between the two warring sides, scientific creationism on the right and evolutionism neoDarwinism on the left, Intelligent Design enters the battlefield in the middle. Here, it is important to avoid the repeated mistake of the media and scientific organizations that say ID is just another variant of creationism, because it is not. Creationists reject macroevolution-they deny evolutionary development from one species to another. This group accept microevolution - they accept the kinds of mutations and natural selection that we can see in experiments using fruit flies in the laboratory. The creationists' theological commitment is this: God created each species as independent of each other at the time of creation. On the other hand, the theoretical commitment of the ID group is that evolutionary development is designed by a Transcendent Designer. This kind of creation allows for macroevolution, although it does not necessarily require it (Peters, 2006: 106).

The group that is often considered contrary to Darwin's theory of evolution is creationism, which believes that living things of all kinds were created by God. Living things are created separately (there is no common ancestor, or that one kind of living thing is not descended from another kind of living thing). The creationist group first emerged among Literalist Christians who could not accept Darwin's theory of evolution because it was considered contrary to the 
narrative of the six-day creation story in the Book of Genesis in the Old Testament, but later it also emerged among Muslims (even though in fact there is no such thing in the Qur'an, specific creation narrative as in Genesis). The reason for the rejection of some religious groups may be due to the assumption that evolution eliminates the role of God in creation, or even that Darwin's theory of evolution supports atheism, although Darwin's theory of evolution as a science cannot interfere with the issue of Divine action, which is in the realm of faith, meaning that it is outside science.

The creationist group has done a lot of criticism of Darwin's theory of evolution. The creationist group explains that if Darwin's theory of evolution is correct there should have been a large number of transitional species during the very long period of change as transitional forms. The remains of these transitional creatures should be in the fossil record. Until now the transition form is very difficult to find. Likewise, transitional areas that have transitional living conditions are currently not found in transitional species with close kinship. So according to the group of creation each species first appeared in a perfect state as we find it today, through the process of creation. Thus the creationist group also believes that it is impossible for an animal to have a structure and habit formed from the modification of a previously living animal with a completely different structure and habit.

As for the instincts possessed by animals, it is impossible to obtain from being modified through natural selection because these instincts are possessed by animals gifted from the Creator. Likewise, nowadays it is known that there are strict boundaries between different species in mating, therefore it is difficult to accept that new species can be obtained by interbreeding their varieties. The creation group also provides an explanation that the oldest layer of the earth where the fossils of living things were found simultaneously is the Cambrian layer, which is estimated to be 500-550 million years ago. From the findings of these fossils, it is known that living things appeared simultaneously so that in the geological literature it is called the Cambrian Explosion (Cambrian Explosion).

\section{Literature Review}

The discipline of evolutionary biology can be defined to some degree as the continued efforts of Darwin's intellectual heirs to arrive at terms with the strong influence of Darwin's theory of evolution. Darwin based his theory of natural selection, which is a core component of his view, on two arguments. First, plants and animals usually produce many offspring beyond the capacity of their environment (Darwin borrowed this idea from the British economist Thomas Malthus). Second, their offspring are slightly different from their parents and from each other (Horgan, 2005: 153).

Although it is recognized that there are doubts about evolutionary events, as stated by Alberts, et al. (1994: 2) that the discussion of cells in terms of evolution can be dangerous, because most of our knowledge about evolution is nothing more than speculations which in their detailed description may be wrong. We cannot go back in time to witness the unique molecular events that occurred billions of years ago. However, it is believed that every organism and all the cells that make it up, must have originated from or descended from an ancient type of cell through evolution. Evolution in this case goes through two main processes: first, the occurrence of random variation of genetic information that is passed from an individual to his offspring, and second, sorting according to genetic information that has 
helped the owner survive and reproduce. Evolution, which is a major stepping stone in biology, has helped in understanding why the living world is so full of diversity.

In the book The End of Science, Horgan (2005: 154) explains that Darwin can only guess what causes all the important variations between generations. In The Origin of Species, first published in 1859, written a view by the French biologist Jean-Baptise Lamarck, that organisms can pass on to their offspring not only inherited traits (from their parents) but also traits that are obtained (from the course of his life). For example, a giraffe's neck that remains stretched out to reach for leaves in tall trees will alter sperm or ovaries so that its young will be born with longer necks. Darwin was clearly uncomfortable with the view that adaptation is self-created. He rather thought that variations in heredity occurred randomly, and only under the pressure of natural selection did variations adjust to eventually lead to evolution.

In 1937, Theodosius Dobzhansky, an orthodox Christian and biologist, published his book The Genetics and The Origin of Species so that Darwin's theory of evolution and Mendelian genetics could be combined to explain the process of evolution and gene change in populations (synthesis theory). Advances in biology continued to increase and confirmed Darwin's theory of evolution. In 1953 James Watson and Francis Crick discovered the structure of DNA (Deoxyribose Nucleic Acid) as hereditary material that contains chromosomes in each cell nucleus. DNA contains hereditary information in the form of amino acid sequences in proteins and enzymes so that molecular biology is born. Molecular biology allows the research of living things on planet earth to be more and more verifiable through their gene frequencies, although of course the slight percent difference is very significant in the final form (phenotype). With a molecular biology approach, human genes are known to be closest to chimpanzees which have 91\% similarity (Indriati, 2006: 101-102).

The long-standing stalemate between supporters of natural and artificial classification systems was largely broken in zoological taxonomy through the success of Darwin's theory of evolution, which is based on natural selection. As Darwin pointed out, the species resulted from organic evolution are not eternally immutable natural entities, nor are they mere fictions. Coherent populations, which isolate themselves, have a true, albeit temporary, reality and are protected by the processes of natural selection and the possibility of variation. In some areas of thought the identification and classification of empirical materials has the opportunity to raise philosophical questions that are easy to erupts conflict (Ravertz, 2004: 143).

The change that causes a type of living thing to advance to a higher degree is called macro-evolution, and that is what is generally meant by the word evolution. So, to explain the way of evolution must distinguish between micro-evolution - macro-evolution. Microevolution is evolution that occurs within a particular species, or that results from interbreeding with close species. The evolution of this species is one hundred percent justified because it is carried out by humans in breeding sites or in plant laboratories, to improve seeds. Macroevolution, as explained above, is a change that makes a type of living thing rise to a higher degree. For example, a fish becomes a snake, a snake becomes a bird, and so on. Such changes appear to contain new organs, such as legs, wings, lungs. We must not speak of the facts witnessed here, for man has never witnessed the transformation of a fish into a snake, or a snake into the form of a bird. However, molecular biology confirms that such changes are possible thanks to mutations in the genetic code or the timing of embryonic development (Leahy, 2002: 65-67).

After Jean-Baptise de Monet Lamarck (1744-1829), and especially after Charles Darwin (1809-1882), biologists sought to discover how evolution occurred. The factors used in the nineteenth century can account for, for the most part, micro-evolution alone. Lamark 
emphasizes the influence of the environment and the adaptation of living things to that environment. Darwin underlined natural selection through the struggle for life

To create macro-evolution, biology must be used. The science has seen spectacular advances since it illuminates the radical role of the genetic code etched in the cell nuclei of living things. This code controls the entire development of the organism. It is at this level that the essential processes of evolution, especially macro-evolution, must be placed, because modifications of the genetic code can account for the birth of new organismal structures, but it is still necessary to find the causes of these new mutations. This is not yet satisfactory at all, because it relies solely on accidental mutations to explain the ascending movement, and the finality of the evidence that characterizes that movement. The role of molecular biology was unknown when Darwin dealt with the problem of evolution, and it was also a deficiency that Darwin's current followers, often called neo-Darwinism, attempted to fill.

Science is a way to know things based on descriptions that can be retested and obtained through human interpretation of observable natural data. Science assumes that everything can be explained materially. Evolution extends the scope of materialistic explanations to living things. This theory incorporates positivism in biology, namely by explaining humans and life from the materialistic side.

Evolution is the most important concept in biology. In fact, a geneticist, Dobzhansky (1973), says that nothing makes sense in biology except from an evolutionary point of view. The theory of evolution explains why millions of species can exist. This principle unifies the entire history of life. In summary evolution states that the diversity of life forms arose as a result of changes in their genetic makeup. Modern organisms are descendants of earlier modified life forms. The study of biological evolution requires a great deal of understanding of genetics, biochemistry, embryology, biogeography, geology, biology, paleontology, molecular biology, and so on.

Ironically, although the idea of evolution has been accepted by most scientists, this idea is widely opposed by society because of its contradiction with some aspects of the teachings of some religions. The most controversial of this theory is its attempt to explain the origin of man from natural processes. Quthub (1986) rejects it on the grounds that there is no purpose in the evolutionary process, even though God created the world with a specific mean and purpose. This theory is also considered to endanger the faith of students. It is feared that students' religious beliefs will be shaken and may fade. It is further said that the theory of evolution is clearly contrary to the principles of Islamic aqidah, so that Muslims must choose one of two things: faith or evolution. In recent times, the controversy has intensified with the publication of books by Harun Yahya which popularized the contradictions of Islam with evolution.

The situation is made worse by an atheistic interpretation of the theory of evolution. Richard Dawkins (1995) asserted that it was impossible to become a true atheist before the publication of Darwin's book On the Origin of Species. This theory is considered to provide a solid scientific basis for atheistic beliefs. Futuyma (1986) states that religion becomes useless with the explanation of evolution. Conflicts about evolution are very difficult to reconcile because of the vast areas of dispute, namely science, philosophy, and theology. Each group tries to look at it from its own field of specialization without feeling the need to know the point of view or its relationship to other fields. In addition, although this theory has attracted the interest of the wider community, there are still many misconceptions about the idea of evolution.

Today, many efforts have been made to reconstruct the paradigm of the integration of science and technology and Islam. Since evolution is the sharpest thorn in the relationship 
between science and religion, it is interesting to examine some important aspects of the theory of evolution and its relationship to religion. This paper aims to describe some important aspects of the theory of evolution and some of its relevance to religious understanding. It is hoped that the correct understanding of the public about the theory of evolution can provide a proportional assessment.

\section{Research Methods}

Before the emergence of the theory of Evolution by Charles Darwin, there was actually a French-born figure who stated about the existence of evolution in living things, namely Jean Baptist Lamarck. Lamarck stated that living things pass on the traits they acquire during life to the next generation. Lamarck argues that the giraffe we see today is an evolutionary animal that was once a deer-like animal with a small body and short neck. However, because they have to compete for food, they have to crane their necks continuously to get leaves on trees that are taller than their body size. Giraffes that are not able to adapt to these conditions will die, while giraffes that successfully compete will stay alive and produce offspring. Because the competition process took a very long time, only the long-necked giraffes were left alive. It is this long-necked giraffe that has produced the offspring of the long-necked giraffe to this day. According to Lamarck, the shape and nature of physical activity is hereditary, meaning that it can be passed down to offspring.

Lamarck's opinion above, it is very difficult to be accepted by reason or common sense. How is it possible that in the era of millions of years ago short-necked giraffes had to fight for leaves to meet their food needs? Isn't the tree that provides the leaves abundantly available with varying ages so that the size of the tree also varies greatly. This makes it easier for the short-necked giraffe to get the leaves as a food source.

Another thing that causes Lamarck's opinion to be unacceptable is the emergence of Genetics, which was pioneered by Mendel. It is common knowledge that the form and nature of living beings' bodies acquired through activity or practice are things that cannot be passed down. Bears that trained to be able to ride a bicycle, so this kind of ability obviously cannot be passed down to the offspring of the bear. A bodybuilder due to training in physical activity has such a physical form as we see bodybuilders. Of course, the shape and nature of the body of the bodybuilder will never be passed down to their children automatically.

Darwin's Theory of Evolution can be defined that all living things undergo changes in both physical and character changes due to adaptation to the existence of Natural Selection. These changes occur gradually from simple forms and characteristics to more advanced forms and properties in a very long time, so that new individuals are formed that are different from their ancestors.

Based on Darwin's Theory of Evolution as explained earlier, this will result in several consequences that must be answered or fulfilled. The consequences are: (1) There should be many types or intermediate species, both in the form of fossils and those living at this time. (2) Physical changes and characteristics of living things that occur due to evolution are permanent. Of course, these forms and properties cannot change back to the forms and properties that their ancestors had in the past. (3) It is impossible for types or species of living things at this time or at any time to live together or live in the same time as their ancestors. (4) It can no longer be found types or species of living things that have simple shapes and characteristics because all types or species of living things have turned into complex ones. (5) 
The first living creatures on earth are found which are the ancestors or pioneer of all living things that inhabit the earth, both those that have become extinct and become fossils as well as billions of types or species of living things that inhabited the earth at the time.

Of the five consequences that arise as a result of Darwin's theory of evolution it turns out that all or none of them can be fulfilled. This shows that Darwin's theory of evolution is scientifically unacceptable. This has led to many responses to Darwin's theory of evolution such as the Father of Genetics Mendel, Georges Cuvier, and Adnan Oktar, better known as Harun Yahya. All of their responses prove the untruth of Darwin's theory of evolution.

\section{Results and Discussion}

As reported by the Republika Daily, Tuesday, June 27 2006, in the science and technology and health rubric, evidence was found that the Sea King Coelacanth (Latimeria chalumnae) is still alive. Sasongkojati (2007) in the Science rubric published by Kompas Daily reported the rediscovery of the Coelacanth titled Sea King Caught in Manado Bay, as follows:

Heart felt amazed and pity when first saw a Coelacanth caught in Manado Bay, North Sulawesi, Saturday (19/05) morning. This fish is also named Latimeria chalumnae Smith in honor of the fish expert from the University of Rhodes, Prof. J. L. B. Smith. Previously, similar fish were found around the Comoros Islands in the Indian Ocean, Mozambique and Madagascar. This terrifying creature is so famous because of its figure that seems to contradict Darwin's theory of evolution. Imagine, this fish species has not experienced changes in body anatomy for millions of years like the fossils of its ancestors aged between 70 million years to 360 million years.

On that sunny Saturday morning, the Coelacanth weighing 60 kilograms with a length of 130 centimeters $(\mathrm{cm})$ and a width of 46 centimeters was accidentally lured by two local fishermen, namely Justinus Lahama and his son, Delvi Lahama; near Malalayang beach, Manado. They had only been fishing for a few minutes at a depth of 70-100 meters when the fishing line shook and felt heavy. When the fishing line is pulled there is no significant resistance. But this strange female fish with fins that look like small hands only goes berserk after being placed in the boat.

A fisherman then reported the findings to the local authorities. Since then, there has been an uproar on the beach, which is known as the culinary center in Manado City. Finally this news reached the Governor of North Sulawesi SHS Sarundayang, who immediately coordinated the rescue of the Coelacanth. Minister of Maritime Affairs and Fisheries Freddy Numberi (at that time), who happened to be on duty in North Sulawesi, had witnessed the rare fish.

At 13.00 the poor fish were brought to the fish recovery pond at City Extra Restaurant, Kalasey, while receiving treatment by the owner of restaurant, Willem Inkirawang, and observed by a local employee, Saman Kamea. For several hours the fish had improved, indicated by movement in the fins. However, due to injuries, stress, and unsuitable environmental conditions, finally at 23:40 pm, Saman Kamea confirmed the found Coelacanth had stopped breathing. It only survives for 17 hours. His body was then wrapped in plastic and put in the freezer to await further treatment from the expert team.

The discovery of this ancient fossil fish is the latest discovery after a video recording of research results in the waters of the Sulawesi Sea in June 2006. It is known that the first 
discovery of a dead Coelacanth in a market in Manado occurred in 1997 by Dr. Mark V Erdmann of the University of California at Berkeley, USA, and his wife, Arnaz Mehta. It was only on July 30, 1998, that Erdmann managed to catch a fish about 1.5 meters long and weighing 45 kilograms which was caught by a fisherman's net, Lameh Sonathan, around Manado Tua Island, North Sulawesi, which is $10,000 \mathrm{~km}$ from the Comoros Island. This fish had lived for about three hours before being preserved and stored in the Zoology Building, Center for Biological Research, LIPI Cibinong, Bogor.

Two other Coelacanths were recorded at a depth of 145 meters on the Sulawesi seabed in 1999, during an expedition carried out by researchers from the Max Planck Institutes using the Baruna Jaya VIII Ship. Even though it was only a video recording, the subsequent findings still shocked the world. Furthermore, in collaboration with researchers from the LIPI Oceanographic Research Center and Aquamarine Fukushima, Japan, they managed to record its presence using an underwater camera carried by a remotely operated vehicle on May 31 June 4, 2006. At that time the team managed to photograph five coelacanths. The five were caught on camera in several different places at a depth of more than 150 meters. The discovery of the Coelacanth in Manado was very surprising because scientists suspected the fish had become extinct before being rediscovered on the east coast of Africa in 1938 and for the next 60 years it was not found anywhere else in the world.

Prof. Hans Fricke of the Max Planc Institutes, Seewiesen, Germany, is the scientist who is most actively investigating the Coelacanth. After the death of three divers on an expedition in South Africa who managed to find the coelacanth's living habitat at a depth of 100 meters in 2000, he created his own submarine for the sake of safe diving. He managed, for the first time, to find the habitat of this ancient fish at a depth of between 150-200 meters, living in Manado as Latimena menadoensis by the Comptes Rendus de L'Academie des Sciences in March 1999 because of the different morphological and genetic characteristics of the Latimena chalumnae fish species in the Comoros Islands, Africa. Prof. Hans Fricke said the results of DNA tests showed that the Manado Coelacanth was different from the African species, and even came from an older species. From the differences of fin shape, the number of fin fingers, different colors and a total of 52 percent of other differences, clearly proves this fish is a new species in the world.

Seeing the shape of this fish, it is appropriate if we consider it a living fossil. According to Wikipedia, Coelacanth itself comes from the Greek, which means spines with holes in the fins. Coelacanths are also called ancient fossil fish because, based on their fossils, this type of fish first appeared in the Devonian era (about 400 million years ago) or much older than the dinosaurs in the Triasix period (about 200 million years ago). Prof Fricke said that this type of fish is known to live in underwater caves at a depth of 150-200 meters with a temperature of 18 degrees Celsius. Coelacanths are also classified as fish that undergo fertilization in the body and give birth to children. Fricke added that the presence of flesh-lobby fins resembling the protrusions of the legs and arms, this fish is assumed to be more closely related to quadrupeds (tetrapods) and lung fish than to the types of fish commonly seen.

This fish is thought to have a close evolutionary relationship with the first fish that lived on the coast before living on land about 360 million years ago. This is because the shape of the Coelacanth's fin is thought to be the first development of the evolution of fins into limbs. In addition, Prof Fricke also believes that the origin of the Coelacanth is in the Pacific region which then spread to the east coast of South Africa 3.5 million years ago when the Indonesian archipelago was formed. As is known that the Coelacanth including animals that are slow to develop. From the original population of around 650 individuals in the Comoros in 1989, then in 1995 it has shrunk to half and is currently estimated to be only 200 individuals. 
Therefore, as a person who cares about the preservation of nature, the author suggests that it is appropriate to establish a special research agency for Coelacanth fish and in line with that conservation efforts should be carried out. LIPI (Indonesian Institute of Sciences) in collaboration with the Ministry of Marine Affairs and Fisheries as well as the North Sulawesi Provincial Government and Sam Ratulangi University must immediately plan and implement activities with the main agenda of saving and preserving Coelacanths. At the 2009 World Ocean Conference in Manado, the Coelacanth will be the mascot.

\section{Conclusion}

Although the theory of evolution is considered by many scientists as a challenge to the beliefs of some religious, ethical, and even scientific beliefs of its time, referring to all the verses of the Qur'an regarding the creation of man, we find that the Qur'an will not face these challenges. at all. This is because the verses in it correspond to the direct creation of man, rather than the gradual and gradual creation, or can be taken as an implied meaning. Humans from Adam's generation can be considered the exception to this theory. However, if there are Muslim scholars who accept the theory of evolution, they believe that the structural uniformity of living things is the result of divine thought rather than mere random coincidences in nature. The facts of human thought are expressed in descriptions and theories in various writings that inspire alongside generations and after. A theory becomes a scientific truth when it can be proven through experimental facts. Likewise the experts and scientists revealed in the historical facts above. There have been many conflicting views since the origination of the term evolution to the present day. However, each argument has its own reason or basis. The science of evolution will continue to evolve and undergo many phases, likely to remain in controversy. It all comes back to how we look and the extent to which we have knowledge and faith. However, it must be remembered that we must still rely on scientific evidence to guide our belief in the truth of a statement.

\section{References}

Albert, Bruce, Dennis Bray, Julian Lewis, Martin Raff, Keith Roberts, and James D. Watson. 1994. Cell Moleculer Biology. Translated by: Alex Tri Kantjono W. Second Edition. PT. Gramedia Pustaka Utama. Jakarta.

Darwin, Charles. 2003. The Origin of Species. Translated by: National University Translating Center Team. First Edition. Yayasan Obor Indonesia. Jakarta.

Fananie, Zainuddin. 1994. “Introductory”. M. Thoybi (Ed.). Science Philosoohy and It's Development. Muhammadiyah University Press. Universitas Muhammadiyah Surakarta. Surakarta.

Haught, John F. 2003. God After Darwin. Translated by: Saut Pasaribu. First Print. Ikon Teralitera. Yogyakarta.

2004. Science and Religion: From Conflict to Conversation. Translated by: Fransiskus Borgias. First Print. Mizan. CRCS (Center for Religious and Cross-Cultural Studies) Graduate Program, Gadjah Mada University. Islamic College for Advanced Studies. Bandung. Yogyakarta. Jakarta.

Higgin, Graham. 2004. Philosophy Anthology. Translated by: Basuki. First Print. PT. Bintang Pustaka. Yogyakarta. 
Horgan, John. 2005. The End of Species. Translated bt: Djejen Zainuddien. First Print. Teraju Press. PT. Mizan Publika. Jakarta.

Huxley, Julian. 2003. "Introductory" in The Origin of Species. Translated by: National University Translating Center Team. First Edition. Yayasan Obor Indonesia. Jakarta.

Indriarti, Etty. 2006. Biological Time and Evolution. Zainal Abidin Baqir, Like Wilardjo, Arqum Kuswanjono, Mohammad Yusuf (Ed.). Science, Ethics, and Religion: Uncover Nature and Humankind. First Print. CRCS (Center for Religious and Cross-Cultural Studies) Graduate School, Gadjah Mada University. Yogyakarta.

Leahy, Louis. 2006. Human Horizon, from Science to Wisdom. Fifth Print. Kanisius. Yogyakarta.

Nasoetion, Andi Hakim. 1988. Introduction to Science Philosophy. Litera Antar Nusa. Jakarta.

Peters, Ted. 2006. Science and Faith: From War to Conformity. Ted Peters, Muzaffar Iqbal, Syed Nomanul Haq (Ed.). God, Nature, and Human: Sciencr and Religion Perspective. First Print. Mizan. Bandung.

Ravertz, Jerome R. 2004. Science Philosophy, History and Scope of Discussion. Translated by: Saut Pasaribu. First Print. Pustaka Pelajar. Yogyakarta.

Sasongkojati, Agung. 2007. Sea King Caught in Manado Bay. Kompas Daily, May 23 $3^{\text {rd }}, 2007$.

Siswomihardjo, Koento Wibisiono. 1994. Science Philosophy Birth History and It's Development. M. Thoybi (Ed.). Science Philosophy and It's Development. Muhammadiyah University Press. Universitas Muhammadiyah Surakarta. Surakarta. 